\title{
Peran Gaya Mengemudi Terhadap Perilaku Mengemudi Beresiko pada Pengendara Sepeda Motor di Kota Malang
}

\author{
Yunda Megawati, Shinta Dewayani \\ yundamega80@gmail.com \\ Jurusan Psikologi, Universitas Brawijaya, Malang, Indonesia
}

\begin{abstract}
This study aims to investigate the role of driving style towards risky driving behaviour among motorcyclists in the City of Malang. This study applied quantitative approach by using correlational technique with total sample of 89 motorcyclists in Malang. Data collection instruments employed in this study were Multidimensional Driving Style Inventory adapted and modified from Taubman-Ben-Ari, Mikulincer, and Gillath's (2004) scale and Risky Driving Behaviour Scale by Iversen (2004). Data analysis for this study was multiple linear regression to find the most contributing aspects of driving style to risky driving behaviour. The results showed that driving style has a role to risky driving behaviour among motorcyclists in Malang. The construct can serve as a basis for community intervention, such as socialisation and safety campaign.
\end{abstract}

Keywords: driving style; motorcycle driver; risky driving behavior

Penelitian ini bertujuan untuk mengetahui peran gaya mengemudi terhadap perilaku mengemudi beresiko pada pengendara sepeda motor di Kota Malang. Penelitian ini menggunakan desain kuantitatif korelasional dengan jumlah sampel penelitian sebanyak 89 responden yang merupakan pengemudi sepeda motor di Kota Malang. Instrumen yang digunakan dalam penelitian ini adalah Skala Multidimensional Driving Style Inventory (MDSI) yang diadaptasi dan dimodifikasi oleh peneliti berdasarkan dari teori Taubman-BenAri, Mikulincer, dan Gillath (2004) dan Skala Risky Driving Behavior (RDB) yang diadaptasi dan dimodifikasi oleh peneliti berdasarkan dengan teori dan dimensi dari Iversen (2004). Analisis data yang digunakan dalam penelitian ini adalah regresi linier berganda untuk menemukan dimensi gaya mengemudi yang paling berperan terhadap perilaku mengemudi beresiko. Hasil penelitian menunjukkan terdapat peran gaya mengemudi secara signifikan terhadap perilaku mengemudi beresiko pada pengendara sepeda motor di Kota Malang. Konstruk tersebut dapat menjadi dasar untuk mengadakan intervensi dalam bentuk sosialisasi dan propaganda kepada masyarakat untuk mengemudi secara aman.

Kata kunci: gaya mengemudi; pengendara sepeda motor; perilaku mengemudi beresiko

Received: August 12, 2018 Accepted: December 24, 2018

How to cite: Megawati, Y. (2018). Peran Gaya Mengemudi Terhadap Perilaku Mengemudi Beresiko pada Pengendara Sepeda Motor di Kota Malang. MEDIAPSI, 4(2), 92-101. doi: https://doi.org/10.21776/ub.mps.2018.004.02.5

\section{Pendahuluan}

Data Satuan Lalu Lintas (Satlantas) Polres Malang (2017) menunjukkan bahwa kecelakaan pengendara sepeda motor menempati persentase lebih besar dibanding kecelakaan kendaraan lainnya, atau sekitar 75 persen. Dari 536 kejadian kecelakaan, sejumlah 402 terjadi pada pengendara sepeda motor. Pengendara sepeda motor harus mempunyai surat ijin mengemudi atau SIM C sebagai lisensi resmi mengemudi di jalan raya. SIM C baru dapat diperoleh jika sudah lulus dalam melakukan ujian tulis dan ujian praktek serta sudah berusia 17 tahun. Hal ini telah diatur dalam Undang-undang Republik Indonesia Nomor 22 Tahun 2009 Tentang Peraturan Lalu Lintas dan Angkutan Jalan Pasal 1 Ayat 23 bahwa pengemudi adalah orang yang mengemudikan kendaraan 
bermotor di jalan dan telah memiliki SIM atau Surat Izin Mengemudi.

Terkait kecelakaan pengendara sepeda motor, terdapat data yang menunjukkan bahwa kesalahan manusia (human error) menyumbang persentase paling tinggi, yaitu 85 persen jika dibandingkan penyebab lainnya (Satlantas Polres Malang, 2017). Fakta tersebut juga diperkuat oleh Yogatama (2013) yang menyebutkan bahwa penyebab kecelakaan lalu lintas khususnya pada pengendara sepeda motor paling banyak disebabkan oleh faktor human error sebesar 67 persen. Sedangkan faktor lainnya, seperti kondisi jalan seperti rusak, bergelombang dan unsur lingkungan misalnya hujan mencapai 33 persen. Lalu sisanya, seperti kendaraan tak laik jalan dan sebagainya mencapai 3 persen. Berdasarkan data dari sejumlah kecelakaan sepeda motor yang telah terjadi tersebut, diketahui bahwa jumlah kematian terbanyak dialami oleh pengendara sepeda motor yang melanggar aturan lalu lintas, terutama yang berkaitan dengan penggunaan helm standar.

Bentuk kesalahan manusia dalam berkendara tersebut dapat berupa pengendara yang lengah dan pengendara yang tidak tertib berlalu lintas yang dapat dikategorikan sebagai perilaku mengemudi yang berpotensi menimbulkan resiko (risky driving behaviour). Risky driving behaviour merupakan perilaku yang dilakukan secara sadar dan dapat berakibat pada terjadinya resiko kecelakaan berkendara. Perilaku yang termasuk dalam risky driving behaviour antara lain berkendara dengan kecepatan tinggi dan berkendara dengan tidak menggunakan alat keselamatan berkendara (Fergusson, Campbell, \& Horwoord, 2003).

Risky driving behaviour adalah salah satu bentuk perilaku mengemudi yang berisiko atau berbahaya. Pengendara berisiko adalah istilah yang digunakan untuk menjelaskan perilaku pengendara yang berpotensi menyebabkan meningkatnya risiko kecelakaan, seperti melanggar lalu lintas, melebihi kecepatan dan sikap sikap yang terkait dalam keselamatan lalu lintas (Yilmaz \& Celik, 2006). Iversen (2004) mengemukakan konsep mengenai risky driving behaviour sebagai perilaku membahayakan diri sendiri maupun orang lain serta ditandai dengan pelanggaran lalu lintas. Dalam konsepnya tentang risky driving behaviour, Iversen (2004) juga menjelaskan adanya dimensi favorable dan dimensi unfavorable di dalamnya. Dimensi favorable yaitu melanggar peraturan lalu lintas (speeding), mengemudi dengan nekat (reckless driving), tidak menggunakan perlengkapan pengamanan berkendara (not using seat belt), mabukmabukan saat berkendara (drinking and driving), dan mengemudi dengan kecepatan rendah (driving below speed limits). Dimensi unfavorable meliputi perilaku terlalu waspada dan hati-hati (cautious and watchfull driving) dan perhatian pada anak-anak saat berkendara (attentiveness toward children in traffic).

Berdasarkan penelitian yang dilakukan oleh Bianchi dan Summala (2004), disebutkan bahwa gaya mengemudi dapat memengaruhi perilaku mengemudi berisiko atau risky driving behaviour. Hasil penelitian yang dilakukan oleh Putri dan Nu'man (2016) juga menyatakan bahwa driving style memiliki hubungan terhadap risky driving behaviour. Driving style juga dipandang sebagai salah satu variabel yang dapat memunculkan perilaku mengemudi berisiko. (Miller \& Taubman-Ben-Ari, 2010).

Driving style adalah segala perilaku mengemudi yang dipilih oleh dirinya sendiri 
sesuai dengan kebiasaan dan kemampuan mereka (Miller \& Taubman-Ben-Ari, 2010). Driving style adalah bagaimana seseorang mengendarai kendaraan bermotor sesuai dengan kebiasaan dan kemampuan yang mereka miliki, misalnya dengan tingkat kecepatan laju kendaraan yang sedang dikemudikan atau hal-hal lain sesuai dengan apa yang mereka pilih. Dalam penelitian yang dilakukan Bianchi \& Summala (2004) driving style juga dapat dipengaruhi oleh peran orang tua, di mana orang tua tidak hanya memberikan anak mereka contoh untuk kehidupan akan tetapi juga memberikan contoh driving style, hal tersebut mencerminkan faktor kognitif dan juga motivasi.

Zimbardo, Keough, dan Boyd (1997) dalam penelitiannya juga menguatkan bahwa faktor manusia menjadi penyebab utama dari kecelakaan berkendara. Faktor manusia dalam berkendara terdiri dari dua elemen, yaitu keterampilan mengemudi dan gaya mengemudi. Menurut Fergusson, Campbell, dan Horwoord (2003), kecelakaan umumnya terjadi antara rentang usia 16-30 tahun, di mana pada usia tersebut pengendara muda memiliki gaya mengemudi yang berbeda beda. Dalam penelitian itu dijelaskan bahwa pengemudi usia muda lebih cenderung untuk melakukan tindakan berkendara yang lebih beresiko dibandingkan dengan usia tua. Penelitian Skvirsky, Taubman-Ben-Ari, Greenbury, dan Prato (2017) menunjukkan bahwa dimensi positif dari keluarga terkait dengan mengemudi yang aman di antara pengemudi muda. Ketika orang tua menjadi panutan yang lebih baik, memberikan umpan balik yang mendorong dan memberdayakan untuk berkendara yang aman, memungkinkan komunikasi yang lebih terbuka, menyampaikan pesan yang lebih jelas mengenai berkendara yang aman, memantau mengemudi mereka ke tingkat yang lebih tinggi, dan cenderung menetapkan batasan yang jelas dalam melanggar undang-undang lalu lintas, pengemudi muda cenderung mendukung gaya mengemudi yang lebih sabar dan hati-hati dan gaya yang kurang sembrono, ceroboh, marah, dan bermusuhan. Berdasarkan penelitian-penelitian tersebut, maka dapat disimpulkan bahwa gaya mengemudi merupakan hasil dari pembentukan perilaku dalam proses belajar yang diperoleh individu dari lingkungannya. Gaya mengemudi yang diperoleh dari proses belajar tersebut sifatnya menetap dan menentukan tingkat keterampilan mengemudi individu.

Secara lebih spesifik, gaya mengemudi (driving style) memiliki hubungan dan berkontribusi dalam penyebab kecelakaan berkendara. Taubman-Ben-Ari dan Yehiel (2012) menjelaskan gaya mengemudi adalah bagaimana cara seseorang memilih model berkendaranya, mulai dari kecepatan dan kesigapan dalam mengemudi, yang kemudian membagi ke dalam empat jenis gaya mengemudi sebagai dimensi dalam gaya mengemudi. Dimensi pertama yaitu gaya mengemudi yang nekat dan ceroboh (the reckless and careless style), di mana pengemudi melakukan pelanggaran dengan sengaja terhadap norma mengemudi yang aman dan pencarian sensual saat mengemudi, yang ditandai dengan kecepatan tinggi dan kelalaian ilegal. Dimensi yang kedua adalah gaya mengemudi pencemas (the anxious style), yaitu pengemudi yang membawa perasaan kewaspadaan dan ketegangan, bersamaan dengan aktivitas relaksasi yang tidak efektif saat berkendara. Dimensi ketiga adalah gaya mengemudi pemarah dan bermusuhan (the angry and hostile style), di mana pengemudi menunjukkan ungkapan iritasi, kemarahan, 
dan sikap bermusuhan dan tindakan di jalan, dan dikecam oleh kecenderungan perilaku agresif, seperti mengutuk atau melontarkan lampu pada pengemudi lain. Adapun dimensi keempat adalah gaya mengemudi yang sabar dan hati-hati (the patient and carefull style), yaitu pengemudi yang memiliki perencanaan ke depan, perhatian pada jalan, kesabaran, kesopanan, ketenangan, dan kepatuhan terhadap peraturan-peraturan lalu lintas yang berlaku.

Dimensi gaya mengemudi yang nekat dan ceroboh, pencemas, pemarah dan bermusuhan memiliki potensi yang sangat dekat dengan mengemudi beresiko. Sedangkan gaya mengemudi yang sabar dan hati-hati tidak terlalu berhubungan dan tidak terlalu berperan dengan perilaku mengemudi berisiko karena dilakukan dengan penuh perencanaan disertai sikap kehati-hatian yang baik, sehingga dinilai tidak dekat dengan perilaku mengemudi yang berisiko (Miller \& Taubman-Ben-Ari, 2010). Penelitian yang dilakukan oleh Putri dan Nu'man (2016) menunjukkan empat hubungan gaya mengemudi dengan mengemudi beresiko, di mana hubungan yang positif terjadi pada gaya mengemudi nekat dan ceroboh dengan mengemudi beresiko, gaya mengemudi pencemas mengemudi beresiko, gaya mengemudi pemarah dan bermusuhan dengan mengemudi beresiko, serta gaya mengemudi sabar dan hati-hati mengemudi beresiko.

Berdasarkan paparan di atas, hasil dari beberapa penelitian menunjukkan hubungan yang positif antara driving style dan risky driving behaviour, sehingga peneliti ingin mengkaji lebih dalam dan melihat bagaimana peran gaya mengemudi terhadap perilaku mengemudi yang berisiko khususnya di Kota Malang.

\section{Metode}

\section{Desain penelitian}

Penelitian ini dapat dikategorikan sebagai penelitian kuantitatif, yaitu pendekatan yang mengukur variasi sebuah situasi atau fenomena sosial dengan menggunakan data berupa angka atau variabel kuantitatif. Variabel dalam penelitian ini terdiri dari variabel bebas atau variabel prediktor, yaitu driving style dan variabel terikat atau kriterium yaitu risky driving behaviour.

\section{Partisipan}

Berdasarkan populasi seluruh pengendara sepeda motor di kota Malang yang sudah berusia tujuh belas tahun ke atas yang menggunakan sepeda motor sebagai alat transportasi, maka responden yang diambil dalam penelitian ini adalah sebanyak 89 orang sesuai dengan perhitungan aplikasi $\mathrm{G}^{*}$ Power 3.1, dengan menggunakan tingkat keyakinan (confidence level) setinggi 95\%, probability of error sebanyak 5\%, dan effect size $15 \%$. Sebanyak sepuluh persen jumlah sampel ditambahkan untuk mencegah data yang eror.

\section{Instrumen penelitian}

Alat ukur yang digunakan untuk mengukur kedua variabel tersebut MDSI (Multidimensional Driving Style Inventory) yang diadaptasi dan dimodifikasi oleh peneliti berdasarkan dari teori Taubman-Ben-Ari (2004) dan sudah diterjemahkan dan disesuaikan ke dalam Bahasa Indonesia. Selain itu, terdapat Skala Risky Driving Behaviour yang merupakan skala yang diadaptasi dan dimodifikasi oleh peneliti berdasarkan dengan teori dan dimensi dari Iversen (2004). Skala ini pun sudah diadaptasi dan diterjemahkan ke dalam tata Bahasa Indonesia. 
Secara keseluruhan, kedua alat ukur menggunakan skala Likert di mana terdapat empat kategori pilihan jawaban, yaitu skor 4 untuk respon sangat sesuai (SS), skor 3 untuk respon sesuai (S), skor 2 untuk respon tidak sesuai (TS), dan skor 1 untuk respon sangat tidak sesuai (STS). Setiap responden harus memilih salah satu dari jawaban tersebut baik itu sesuai ataupun tidak sesuai tetapi responden harus tetap memilih jawaban yang paling mendekati dengan dirinya. Pada pengujian alat ukur, dilakukan pengujian daya diskriminasi butir. Sebagai kriteria pemilihan butir total, digunakan batasan (cut off) $\geq 0.20$, sehingga diperoleh 19 butir pernyataan pada skala driving style dan 23 butir pernyataan pada skala risky driving behaviour yang dinyatakan valid setelah dilakukan uji coba terhadap 30 sampel.

Jenis uji validitas yang digunakan dalam penelitan ini yaitu validitas isi (content validity). Berdasarkan pengujian validitas internal (internal consistency) dan reliabilitas yang dilakukan pada hasil perkalian pasangan butir di masing-masing variabel, didapatkan koefisien Alpha sebesar 0.827 pada driving style dan 0.839 pada risky driving behaviour. Semua hasil perhitungan tersebut menunjukkan bahwa alat ukur dalam penelitian ini dinyatakan reliabel (konsisten) mengukur suatu konstruk/variabel sesuai dengan batasan yang dimiliki.

\section{Teknik analisis data}

Data yang terkumpul kemudian dianalisis menggunakan metode regresi linear berganda (multiple linear regression) karena peneliti ingin melihat peran driving style (the reckless and careless style, the anxious style, the angry and hostile style, dan the patients and carefull style) terhadap risky driving behaviour.

\section{Hasil}

Berdasarkan hasil perhitungan statisitik dengan menggunakan teknik analisis korelasi dan determinasi diketahui bahwa koefisien $r$ antara semua variabel prediktor dan kriterium adalah 0.408 dengan taraf signifikansi sebesar 0.000. Hasil ini menunjukkan bahwa variabel driving style yang terdiri dari the reckless and careless style, the anxious style, the angry and hostile style, dan the patients and carefull style memiliki hubungan yang signifikan dengan risky driving behaviour. Lebih lanjut, dapat diketahui pengaruhnya $\left(\mathrm{r}^{2}\right)$ adalah sebesar $0.288(28.8 \%)$. Nilai pengaruh tersebut dapat digolongkan sebagai efek yang besar (large effect).

Dari pengolahan data dengan teknik analisis regresi linear berganda didapatkan hasil koefisien regresi variable driving style pada gaya mengemudi angry and hostile dengan $p$ sebesar $0.587 \quad(p>0.05)$, yang menunjukkan tidak terdapat pengaruh gaya mengemudi angry and hostile terhadap risky driving behaviour. Demikian pula halnya dengan gaya mengemudi patient and carefull yang menghasilkan p sebesar 0.122 ( $\mathrm{p}>0.05)$, yang juga menunjukkan tidak terdapat pengaruh the patient and carefull style terhadap risky driving behaviour.

Sedangkan untuk gaya mengemudi anxious menghasilkan $\mathrm{p}$ sebesar 0.000 $(\mathrm{p}<0.05)$. Ini menunjukkan terdapat pengaruh gaya mengemudi anxious terhadap risky driving behaviour secara signifikan. Adanya pengaruh juga ditunjukkan pada gaya mengemudi reckless and careless yang bernilai positif dengan nilai signifikansi sebesar $0.000 \quad(\mathrm{p}<0.05)$. Ini menunjukkan terdapat pengaruh the reckless and careless style terhadap risky driving behaviour secara signifikan (lihat Tabel 1). 
Sementara itu, pada Tabel 2, diketahui besarnya koefisien regresi dimensi the reckless and careless style menunjukkan bahwa terjadi hubungan positif antara the reckless and careless style dengan risky driving behaviour sebesar 0.953. Hal ini bermakna jika dimensi the reckless and careless style mengalami kenaikan maka variabel y akan mengalami kenaikan sebesar 0.953. Koefisien regresi dimesi the anxious style menunjukkan adanya hubungan yang positif antara the anxious style dengan risky driving behaviour sebesar 0.895, yang bermakna jika dimesi the anxious style mengalami kenaikan maka variabel y akan mengalami kenaikan sebesar 0.895. Koefisien regresi dimesi the angry and hostile style menunjukkan bahwa terjadi hubungan positif antara the angry and hostile style dengan risky driving behaviour sebesar 0.184, yang bermakna jika dimesi the angry and hostile style mengalami kenaikan maka variabel y akan mengalami kenaikan sebesar 0.184. Koefisien regresi dimesi the patient and carefull style menunjukkan bahwa terjadi hubungan negatif antara the patient and carefull style dengan risky driving behaviour sebesar -0.659 , artinya jika dimesi the patient and carefull style mengalami kenaikan maka variabel y akan turun sebesar 0.659 .

Tabel 1

Hasil Uji Hipotesis Simultan dengan Multiple Linear Regression

\begin{tabular}{lccc}
\hline \multicolumn{1}{c}{ Variabel } & $\begin{array}{c}\text { Koefisien } \\
\text { Determinasi } \\
\left(\mathbf{r}^{2}\right)\end{array}$ & $\begin{array}{c}\text { Nilai } \\
\text { Signifikansi } \\
(\mathbf{p})\end{array}$ & Keterangan \\
\hline $\begin{array}{l}\text { The reckless } \\
\text { and careless } \\
\text { style, the }\end{array}$ & 0.288 & 0.000 & Signifikan \\
anxious style, \\
the angry and \\
hostile style, the \\
patients and \\
carefull \\
style*RDB
\end{tabular}

Sementara analisis regresi secara parsial untuk dimensi the reckless and careless style menghasilkan p sebesar 0.000 atau $p<0.05$, dan ini menunjukkan terdapat pengaruh the reckless and careless style terhadap risky driving behaviour secara signifikan. Sementara itu, dimensi the anxious style menghasilkan $\mathrm{p}$ sebesar 0.000 atau $\mathrm{p}<0.05$, ini menunjukkan terdapat pengaruh the anxious style terhadap risky driving behaviour secara signifikan.

Tabel 2

Hasil Uji Hipotesis

\begin{tabular}{lccl}
\hline \multicolumn{1}{c}{ Variabel } & $\begin{array}{c}\text { Nilai } \\
\text { Beta } \\
\text { (B) }\end{array}$ & $\begin{array}{c}\text { Nilai } \\
\text { Signifikansi } \\
\text { (p) }\end{array}$ & Keterangan \\
\hline $\begin{array}{l}\text { The reckless and } \\
\text { careless style } * R D B \\
\text { the anxious }\end{array}$ & 0.953 & 0.000 & Signifikan \\
style RDB $^{\text {the angry and }}$ & 0.895 & 0.000 & Signifikan \\
$\begin{array}{l}\text { hostile style } * R D B \\
\text { the patients and } \\
\text { carefull style } * R D B\end{array}$ & 0.184 & 0.587 & $\begin{array}{l}\text { Tidak } \\
\text { Signifikan }\end{array}$ \\
\hline
\end{tabular}

Dimensi the angry and hostile style menghasilkan p sebesar 0.587 atau $p>0.05$. Hal ini menunjukkan tidak terdapat pengaruh the angry and hostile style terhadap risky driving behaviour. Sementara itu, dimensi the patients and carefull style menghasilkan $\mathrm{p}$ sebesar 0,122 atau $\mathrm{p}>0.05$, yang menunjukkan tidak terdapat pengaruh the patients and carefull style terhadap risky driving behaviour.

\section{Diskusi}

Hasil analisis di atas menunjukkan bahwa terdapat dua dimensi gaya mengemudi pada variabel driving style yang memiliki pengaruh signifikan terhadap risky driving behaviour. Semakin nekat dan ceroboh (reckless and careless), serta semakin pencemas (anxiety) gaya mengemudi, maka 
akan semakin tinggi resiko mengemudi (risky driving behaviour). Di samping analisis pengaruh tersebut, bila dilihat dari persebaran data pada butir-butir skala risky driving behaviour dan driving style, subjek pada penelitian ini memiliki kecenderungan risky driving behaviour pada kategori sedang sebanyak 64.5 persen. Sementara itu, sisanya sebesar 35.5 persen berada pada kategori rendah dan tidak ada responden yang berada kategori tinggi. Kategorisasi dalam risky driving behaviour dapat dipahami dari kecenderungan skor tinggi pada dimensidimensi favorable dan unfavorable di dalamnya, yaitu melanggar peraturan lalu lintas (speeding), mengemudi dengan nekat (reckless driving), mabuk pada saat berkendara (drinking and driving), tidak menggunakan perlengkapan keamanan berkendara, dan mengemudi dengan kecepatan rendah (speed below limits), terlalu waspada dan hati-hati (cautious and watchfull driving), perhatian pada anak-anak saat berkendara (attentiveness toward children in traffic).

Persebaran data pada variabel driving style menunjukkan pada dimensi the reckless and careless style mayoritas responden berada pada kategori sedang, yaitu sebanyak 76 persen. Dimensi the anxious style menunjukkan bahwa terdapat responden yang berada pada kategori rendah sebesar 41 persen, atau hampir setara dengan responden yang berada pada kategori sedang sebesar 58 persen. Dimensi the angry and hostile style menunjukkan bahwa lebih dari separuh responden berada pada kategori sedang, yaitu sebanyak 59.5 persen. Sementara itu. dimensi the patients and carefull style menunjukkan bahwa mayoritas responden berada pada kategori sedang, yaitu sebanyak 86 persen. Dari persentase data tersebut dapat disimpulkan bahwa gaya mengemudi yang paling dominan dilakukan oleh pengemudi sepeda motor adalah anxious style, yaitu gaya pengemudi pencemas.

Hasil uji hipotesis menunjukkan nilai signifikansi sebesar 0.000 , di mana hasil siginifikansi tersebut lebih kecil dari nilai koefisien 0.05. Dari hasil tersebut menyatakan bahwa hipotesis (Ha) yang diajukan oleh peneliti diterima, yang berarti bahwa terdapat peran driving style $(\mathrm{X})$ terhadap risky driving behaviour $(\mathrm{Y})$ pada pengendara sepeda motor di Kota Malang. Hasil penelitian ini relevan dengan pendapat French dkk. (1993) yang menjelaskan bahwa gaya mengemudi ini mengacu terhadap pelanggaran norma dan mencari sensasi ketika mengemudi sehingga pengemudi mengarah pada perilaku mengemudi berisiko. Menurut Taubman-BenAri, Mikulincer, dan Gillath (2004) gaya mengemudi yang ceroboh juga ditemukan terkait secara positif dengan sejarah pelanggaran lalu lintas individu. Hal itu dibuktikan pada hasil penelitian ini yang juga mendapatkan bahwa gaya mengemudi nekat dan ceroboh memiliki peran yang signifikan terhadap perilaku mengemudi berisiko.

Menurut Gulian dkk. (1989), gaya mengemudi pencemas mencerminkan perasaan waspada dan ketegangan serta keterlibatan yang tidak efektif dalam aktivitas santai selama mengemudi, sehingga dapat mengarah pada perilaku mengemudi yang berisiko. Berdasarkan hasil penelitian, didapatkan bahwa terdapat peran yang signifikan pada gaya mengemudi pencemas terhadap perilaku mengemudi berisiko. Hal ini dikarenakan pengemudi yang sering merasa cemas saat mengemudikan kendaraan akan memiliki perasaan waspada yang tinggi serta akan merasa tertekan. Hal ini dapat mengganggu konsentrasi pengemudi sehingga 
gaya mengemudi pencemas dapat menyebabkan pengemudi memiliki perilaku mengemudi yang berisiko.

Sementara itu, gaya mengemudi pemarah dan bermusuhan tidak memberikan kontribusi terhadap perilaku mengemudi berisiko. Gaya mengemudi yang marah dan bermusuhan mengacu pada ekspresi iritasi, kemarahan, dan sikap bermusuhan dan bertindak saat mengemudi, serta mencerminkan kecenderungan untuk bertindak agresif di jalan, seperti mengutuk pengemudi lain. Dimensi ini menjelaskan bahwa pengemudi cenderung melakukan tindakan agresif seperti mengungkapkan kemarahan dan sikap bermusuhan secara sengaja. Menurut Tasca (2000), suatu perilaku mengemudi dikatakan agresif jika dilakukan secara sengaja, cenderung meningkatkan resiko tabrakan, dan dimotivasi oleh ketidaksabaran, kekesalan, permusuhan, dan upaya untuk menghemat waktu, sehingga dalam hal ini, gaya mengemudi ini cenderung lebih kepada perilaku agresif dalam mengemudi daripada perilaku mengemudi yang berisiko.

Sementara itu, untuk gaya mengemudi sabar dan hati-hati, penelitian yang dilakukan oleh Taubman-Ben-Ari dan Yehiel (2012) menyatakan bahwa gaya mengemudi sabar dan hati-hati memiliki korelasi negatif dengan tingkat kejadian yang berisiko. Menurut Harre dan Parrot (2000), gaya ini mengacu pada perencanaan ke depan, perhatian, kesabaran, kesopanan, dan ketenangan saat mengemudi, serta menjaga aturan lalu lintas. Penelitian ini menunjukkan gaya mengemudi sabar dan hatihati tidak mengarah pada perilaku mengemudi berisiko karena pengemudi yang memiliki gaya sabar dan hati-hati memiliki perhatian, kesabaran, kesopanan, dan ketenangan dalam mengemudi serta selalu memperhatikan dan mematuhi aturan lalu lintas.

Secara keseluruhan, dapat dijelaskan bahwa gaya mengemudi (driving style) memberikan kontribusi sebesar 28.8 persen terhadap perilaku berisiko dalam berkendara (risky driving behaviour). Zayu (2012) menjelaskan adanya faktor-faktor lain yang berkontribusi memunculkan perilaku berisiko dalam berkendara antara lain faktor kesalahan manusia (human error), seperti lalai dalam berkendara, kurangnya konsentrasi, membawa kendaraan sambil SMS, menelpon atau mendengarkan musik menggunakan headphone dan lain sebagainya. Selain faktor kesalahan manusia juga terdapat faktor kondisi jalan dan rambu-rambu lalu lintas yang berpotensi menyebabkan kecelakaan dalam berkendara.

Berdasarkan hasil penelitian tentang peran driving style terhadap risky driving behaviour yang telah dilakukan kepada pengemudi sepeda motor di Kota Malang, maka dapat ditarik simpulan bahwa terdapat peran driving style terhadap risky driving behaviour pada pengemudi sepeda motor di Kota Malang. Uji hipotesis menunjukkan bahwa secara simultan driving style memiliki peran yang signifikan terhadap risky driving behaviour. Berdasarkan pengujian secara parsial yang melihat peran setiap dimensi dalam driving style, diperoleh hasil bahwa pada dua dimensi, yaitu the reckless and careless style dan the anxious style berperan secara parsial terhadap risky driving behaviour memiliki peran yang signifikan terhadap risky driving behaviour, sedangkan dua dimensi lainnya yaitu the angry and hostile style dan the patients and carefull style tidak menunjukkan kontribusinya terhadap risky driving behaviour. 
Berdasarkan penelitian tersebut, yang menunjukkan adanya faktor kesalahan manusia dari gaya mengemudinya yang beresiko dalam berkendara, maka adanya sosialisasi dan propaganda untuk mengemudi secara aman (safety riding) dapat dilakukan secara intensif ke berbagai kelompok masyarakat.

\section{Daftar Pustaka}

Bianchi, A., \& Summala, H. (2004). The "genetics" of driving behavior: parents' driving style predicts their children's driving style. Accident Analysis \& Prevention, 36(4), 655-659. doi: https://dx.doi.org/10.1016/S00014575(03)00087-3

Fergusson, D., Campbell, N. S., \& Horwoord, J. (2003). Risky driving behaviour in young people: Prevalence, personal characteristics and traffic accidents. Australian and New Zealand Journal of Public Health, 27(3), 337-342. doi: https://dx.doi.org/10.1111/j.1467842X.2003.tb00404.X

Gulian, E., Matthews, G., Glendon, A. I., Davies, D. R., \& Debney, L. M. (2007). Dimensions of driver stress. Ergonomics, 32(6), 585-602. doi: https://dx.doi.org/10.1080/00140138908 $\underline{966134}$

Harre, R., \& Parrot, W. G. (2000). The Emotion: Social, Cultural and Biological Dimensions. London: SAGE Publications Inc.

Iversen, H. (2004). Risk-taking attitudes and risky driving behavior. Transportation Research Part F: Traffic Psychology and Behaviour, 7(3), 135-150. doi: https://dx.doi.org/10.1016/j.trf.2003.11. $\underline{003}$

Miller, G., \& Taubman-Ben-Ari, O. (2010). Driving styles among young novice drivers - The contribution of parental driving styles and personal characteristics. Accident Analysis \& Prevention, 42(2), 558-570. doi: https://dx.doi.org/10.1016/j.aap.2009.09 .024

Polres Kota Malang. (2017). Data Laka Lantas 2017. Malang: Satlantas Polres Kota Malang.

Putri, P. N., \& Nu'man, M. T. (2016). Hubungan Gaya Mengemudi (Driving Style) dan Perilaku Mengemudi Beresiko (Risky Driving) Pada Remaja di Yogyakarta. Yogyakarta: Universitas Islam Indonesia.

Skvirsky, V., Taubman-Ben-Ari, O., Greenbury, T. J., \& Prato, C. G. (2017). Contributors to young drivers' driving styles - A comparison between Israel and Queensland. Accident Analysis \& Prevention, 109,

47-54. https://dx.doi.org/10.1016/j.aap.2017.08 .031

Tasca, L. (2000). A review of the literature on aggressive driving research, paper presented at First Global Web Conference on Aggressive Driving Issues, Canada.

Taubman-Ben-Ari, O., Mikulincer, M., \& Gillath, O. (2004). The multidimensional driving style inventory - scale construct and validation. Accident Analysis \& Prevention, 36(3), 323-332. doi: https://dx.doi.org/10.1016/S00014575(03)00010-1 
Taubman-Ben-Ari, O., \& Yehiel, D. (2012). Driving styles and their associations with personality and motivation. Accident Analysis \& Prevention, 45, 416-422. doi: https://dx.doi.org/10.1016/j.aap.2011.08 .007

Yilmaz, V., \& Celik, H. E. (2006). Risky driving attitudes and self-reported traffic violations among turkish drivers: The case of Eskişehir. Doğuş Üniversitesi Dergisi, 7(1), 127-138. Diambil dari: http://journal.dogus.edu.tr/index.php/du $\mathrm{j} /$ article/view/124

Yogatama, L. A. M. (2013, October). Analisis pengaruh attitude, subjective norm, dan perceived behavior control terhadap intensi penggunaan helm saat mengendarai motor pada remaja dan dewasa muda di Jakarta Selatan. Paper presented at the PESAT, Bandung, Indonesia. Diambil dari https://ejournal.gunadarma.ac.id/index.p hp/pesat/article/view/800

Zayu, W. P. (2012). Studi kecelakaan lalu lintas dengan metode 'revealed preference' di Kota Padang. Artikel Tidak Dipublikasikan. Padang: Universitas Andalas.

Zimbardo, P. G., Keough, K. A., \& Boyd, J. N. (1997). Present time perspective as a predictor of risky driving. Personality and Individual Differences, 23(6), 10071023.

doi:

https://dx.doi.org/10.1016/S0191-

$\underline{\text { 8869(97)00113-X }}$ 